\title{
Desain dan Implementasi Audit Operasional pada bagian Perpustakaan SMA Laboratorium Kristen Satya Wacana
}

\author{
Intan Chelsye R \\ Selvi Andriani \\ Intan Putri E \\ Ari Wicaksono \\ Rizky Sandhi Setyaki \\ Intiyas Utami* \\ Suzy Novianti
}

Program Studi Akuntansi, Universitas Kristen Satya Wacana

\section{A R T I C L E I N F O}

\section{Article history:}

Received 3-12-2020

Revised 5-12-2020

Accepted 30-12-2020

Key words:

Audit internal, pengabdian

masyarakat, audit operasional

\begin{abstract}
A B S T R A C T
Community service activities in the field of internal audit are carried out in the Satya Wacana Christian High School to assess the existing $3 E$ (efficient, effective, and economical). The methods in this internal audit activity include identifying risks, audit programs and procedures, interviewing, observing, confirming, distributing questionnaires, and providing recommendations based on audit findings. The results if this activity are in the form of recommendations for prevention, improvement of the library operational activitiesbased of the $3 E$ principle.
\end{abstract}

\section{A B S T R A K}

Kegiatan pengabdian masyarakat bidang audit internal dilakukan di Bagian Perpustakaan SMA Laboratorium Kristen Satya Wacana untuk menilai 3E (efisien, efektif, dan ekonomis) yang ada. Metode yang dilakukan dalam kegiatan audit internal ini diantaranya mengidentifikasi risiko, membuat program dan prosedur audit, wawancara, observasi, konfirmasi, pembagian kuisioner, serta memberikan rekomendasi atas temuan-temuan audit yang diperoleh. Hasil pengabdian masyarakat ini adalah berupa rekomendasi untuk pencegahan, perbaikan, dan pengingkatan kegiatan operasional perpustakaan secara berkesinambungan berdasarkan prinsip 3E.

\footnotetext{
*Corresponding author: intiyas.utami@uksw.edu
} 


\section{PENDAHULUAN}

Perpustakaan adalah satu elemen penting yang mendukung kegiatan pendidikan. Sumber pembelajaran yang baik akan mendorong proses pembelajaran menjadi lebih optimal dan efektif sehingga mampu membantu mewujudkan kualitas pendidikan yang dibutuhkan (Megasari, 2014). Afrina \& Ibrahim (2012) mengatakan bahwa perpustakaan juga merupakan gudang pengetahuan dan informasi yang mendukung pembelajaran dan penelitian pada peserta didik. Tentunya hal-hal tersebut menjadikan perpustakaan salah satu unit dalam organisasi yang harus memiliki fungsi operasional yang maksimal dalam proses-prosesnya seperti halnya pengadaan, pengolahan bahan pustaka, dan pelayanan pustaka. Pramono (2003) mengatakan bahwa peran dan implementasi audit internal sangat diperlukan untuk meningkatkan kinerja operasional organisasi yang salah satunya adalah perpustakaan sekolah.

Praktik-praktik tata kelola yang baik juga menjadi syarat wajib untuk mencapai kestabilan dalam setiap kegiatan operasional organisasi terutama dalam bidang pendidikan. Subamia, dkk (2014) mengatakan bahwa sekolah-sekolah membutuhkan tata kelola yang baik untuk mendukung kegiatannya, karena sekolah dituntut untuk memenuhi kebutuhan masyarakat dalam lewat kurikulum yang disediakan. Hal ini tentunya membutuhkan peran manajemen sekolah yang baik dalam pelaksanaannya. Audit internal adalah salah satu jawaban untuk mencapai tujuan-tujuan tersebut. Organisasi non-profit seperti sekolah membutuhkan audit internal untuk menilai seberapa efektif dan efisien penerapan sistem pengendalian internal (SPI) dalam kegiatan organisasinya. Namun tidak hanya untuk menilai kelemahan SPI, auditor internal dibentuk oleh direksi ataupun pimpinan dengan tujuan menyamakan pandangan/pemahaman semua elemen organisasi mengenai risiko (Karmudiandri, 2014).

Kegiatan pengabdian masyarakat dilakukan pada semester 2 tahun ajaran 2018/2019 dilakukan dalam bentuk audit operasional di SMA Kristen Satya Wacana pada bagian kurikulum, terutama unit perpustakaan. Kegiatan-kegiatan yang dilakukan adalah mengidentifikasi risiko, membuat mapping risiko, merancang Kertas Kerja Audit (KKA), melakukan wawancara dan observasi, mengevaluasi risiko, memberikan laporan audit dan rekomendasi atas pencegahan, penanganan, dan perbaikan pada risiko yang terdeteksi dan yang sudah terjadi sehingga dapat membantu meningkatkan kualitas operasional layanan perpustakaan.

\section{Kajian Teori \\ Audit Internal}

Institute of Internal Auditing (IIA) mengemukakan bahwa audit internal merupakan aktivitas penjamin yang independen dan objektif, dan merupakan suatu jasa konsultasi yang dirancang untuk memberikan nilai tambah dan meningkatkan kinerja suatu organisasi. Audit internal dapat mendukung organisasi dalam mencapai tujuan dengan cara sistematis dan terstruktur dalam meningkatkan dan mengevaluasi efektifitas, efisiensi serta ekonomisasi manajemen risiko, kecukupan pengendalian dan pengelolaan pengendalian (Herawaty, 2013). Sugiman (2017) mengatakan bahwa Audit internal merupakan pengawasan manajerial yang berfungsi menilai dan 
mengevaluasi pengendalian yang bertujuan membantu anggota organisasi dalam mengolah dengan efektif untuk menyediakan analisis, penilaian, rekomendasi, dan komentar-komentar yang berhubungan dengan kegiatan- kegiatan yang ditelaah.

Audit internal dalam sebuah organisasi memiliki sejumlah peran, yaitu memberikan mengawasi dan mengevaluasi prosedur, kebijakan, dan laporan keuangan untuk meningkatkan kualitas penyajian laporan keuangan (Fikri dkk, 2016). Karmudiandri (2014) mengatakan bahwa peran audit internal dalam manajemen risiko yaitu fokus pada tugas audit menyangkut risiko-risiko, mengaudit proses manajemen risiko yang telah dilaksanakan, memberikan penjaminan mutu terhadap pengelolaan risiko, memberikan dukungan aktif terhadap proses manajemen risiko, memfasilitasi dan mengkoordinasi pelaporan risiko kepada Direksi.

\section{Audit Operasional}

Undang-undang No 15 tahun 2004 menyebutkan bahwa audit internal mencakup beberapa jenis audit, yaitu audit keuangan, audit kinerja atauoperasional, dan audit dengan tujuan khusus. Audit kinerja/operasional adalah pemeriksaan atas pengelolaan keuangan negara atas aspek ekonomi, efisiensi, dan efektivitas. Hijayati, Dzulkirom, \& Husaini (2014) menyebutkan bahwa pada hakikatnya audit operasional adalah mengevaluasi efektivitas, efisiensi, dan aspek ekonomis yang akan dijadikan sebagai pertimbangan untuk mengetahui manfaat kebijakan suatu perusahaan.

Audit operasional juga merupakan bagian dari fungsi pengendalian yang menjadi alat bagi manajemen untuk mengukur dan mengevaluasi suatu kegiatan yang telah dilaksanakan (Suharli, 2006). Manajemen harus memperhatikan segala aspek yang ada dalam perusahaan khususnya unsur-unsur yang bisa mempengaruhi besaran laba rugi bagi perusahaan atau surplus-defisit bagi organisasi non-profit. Menurut Wahyuningsih, Halim, \& Wulandari (2016) audit operasional adalah prosedur sistematis yang digunakan untuk mengevaluasi efektivitas dan efisiensi kegiatan pada suatu organisasi demi mencapai tujuan organisasi. Anugrah \& Tugiman (2017) juga menyatakan, audit operasional merupakan aktivitas operasi pada suatu organisasi yang memiliki tujuan untuk memeriksa efisiensi dan efektivitas akan operasional perusahaan. Aktivitas pemeriksaan operasional dapat memberikan banyak manfaat untuk perusahaan karena bisa menunjang kelancaran pelaksanaan operasional perusahaan terhadap keberlangsungan perusahaan dimasa yang akan datang.

Audit operasional dibagi menjadi tiga kelompok berdasarkan aktivitasnya, yaitu berdasarkan unit fungsi organisasi, berdasarkan struktur organisasi, dan dilaksanakan secara khusus. Ada beberapa tahapan yang harus dilakukan dalam audit operasional. Secara garis besar dapat dikelompokkan menjadi lima, menurut Wahyuningsih, Halim, \& Wulandari (2016) yaitu: 1) Audit Pendahuluan, 2) Review dan Pengujian Pengendalian Manajemen, 3) Audit Rinci/Lanjutan, 4) Pelaporan, 5) Tindak Lanjut.

\section{Program Audit}

. Program audit menurut Backlund \& Thollander (2015) adalah langkah-langkah mengevaluasi dan meneliti tingkat efisiensi dan efektivitas suatu kebijakan operasional sebuah perusahaan. Kamal (2012) mengatakan bahwa program audit adalah program rencana kerja audit yang dibuat secara sistematis termasuk sasaran audit yang akan dilaksanakan oleh auditor, digunakan sebagai petunjuk dan alat pengawasan atas pekerjaan audit. Program tersebut berisi arahan-arahan pemeriksaan dan evaluasi informasi yang dibutuhkan untuk memenuhi tujuan audit dalam ruang lingkup 
penugasan audit. Program audit disusun agar bermanfaat guna memberikan rencana sistematis untuk setiap tahap pekerjaan audit, yang merupakan suatu rencana yang dapat dikomunikasikan baik kepada dari auditor kepada pegawai dalam suatu organisasi (Arifah, 2012).

\section{METODE}

Tujuan dilaksanakan kegiatan pengabdian dalm bentuk audit internal ini untuk dapat menilai: 1) Efisiensi kegiatan operasional unit perpustakaan, 2) Efektifitas kegiatan operasional unit perpustakaan, 3) Ekonomisnya kegiatan operasional unit perpustakaan. Ruang lingkup pekerjaan audit internal mencakup semua proses kegiatan operasional unit perpustakaan, dan juga untuk memberikan masukan/saran atas internal control dan risk management. Prosedur yang dilakukan oleh auditor internal yaitu dengan wawancara, observasi, dan pembagian kuisoner kepada pengguna fasilitas/unit perpustakaan. Pihak yang menjadi narasumber dalam proses audit ini adalah Bapak A dan Bapak D selaku petugas perpustakaan.

\section{HASIL DAN PEMBAHASAN}

\section{Penentuan Kriteria}

Dalam penentuan kriteria perpustakaan SMA Laboratorium Kristen Satya Wacana memiliki 3 (tiga) pembagian, diantaranya kriteria pengadaan, pelayanan, dan pengelolaan. Masing masing kriteria memiliki poin-poin sebagai berikut.

Penentuan kriteria oleh tim auditor atas perpustakaan SMA Laboratorium Kristen Satya Wacana dalam bentuk kebijakan atau prosedur operasional standar yang digunakan untuk menguji proses bagian pengadaan yaitu buku dan aset yang sudah dibeli harus sesuai dengan kebutuhan jenis dan jumlahnya, perekrutan petugas perpustakaan harus sesuai dengan jumlah tenaga kerja yang dibutuhkan serta memiliki latar belakang pendidikan dan kompetensi yang relevan.

Kriteria untuk menguji proses bagian pengelolaan yaitu pendaftaran buku baru ke dalam katalog dan data buku, pelabelan buku sesuai dengan data dan katalog, penyusunan buku sesuai dengan jenisnya, perawatan buku dengan memberikan sampul dan memperbaiki cover buku yang terlepas, pembagian tugas dan jam kerja yang jelas terhadap petugas perpustakaan.

Kriteria untuk menguji proses bagian pelayanan yaitu setiap peminjaman buku perpustakaan memiliki syarat-syarat peminjaman seperti kartu pelajar siswa sebagai jaminan, input data peminjaman dan pengembalian buku ke data peminjaman dan pengembalian yang hanya boleh dilakukan oleh petugas perpustakaan, pengawasan dan penanganan buku yang rusak saat dipinjam di perpustakaan, dan pelayanan peminjaman dan pengembalian buku dari membantu pencarian literasi dan pengembalian buku ke dalam rak buku serta mengutamakan kepuasan pengunjung oleh petugas perpustakaan.

\section{Penentuan Prosedur Audit}

Prosedur yang dilakukan oleh auditor internal yaitu dengan wawancara, observasi, dan pembagian kuisoner kepada pengguna fasilitas/unit perpustakaan. Pihak yang menjadi narasumber dalam proses audit ini adalah Bapak Aji dan Bapak 
Dani selaku petugas perpustakaan.

\section{Temuan}

Berdasarkan audit operasional yang sudah dilakukan oleh tim audit internal, ditemukan beberapa hal yang perlu di tangani pada unit perpustakaan SMA Kristen Satya Wacana. Temuan terkait efektivitas yaitu terdapat buku rusak sebanyak kurang lebih 1.232 buku dari jumlah total buku literasi sebanyak kurang lebih 10.300 buku. Kemudian tim audit juga menemukan jumlah karyawan yang tidak sesuai dengan bagan pada struktur organisasi, selanjutnya akses masuk-keluar perpustakaan lebih dari satu.

Temuan terkait efisiensi yaitu buku-buku yang tidak terpakai tersimpan dalam kardus dengan jumlah kurang lebih 8.083 buku dan perkembangan inventaris yang terhambat karena jumlah SDM yang terbatas. Kemudian temuan terkait keekonomisan tidak ada tindak lanjut penerapan software pengelolaan buku perpustakaan, tidak ada loker untuk menyimpan tas dan belum ada prosedur untuk menjamin siswa mengembalikan buku secara keseluruhan.

\section{Sebab dan Akibat}

Kegiatan operasional SMA Laboratorium Kristen Satya Wacana terkait efektivitas pada aktivitas terdapat kondisi yang tidak sesuai yaitu, temuan atas bukubuku yang rusak karena saat mengambil buku siswa kurang berhati-hati, perbaikan buku yang hanya menggunakan isolasi hitam (lakban/cloth tape), usia buku yang sudah cukup lama yang mengakibatkan kerusakan tambahan pada buku. Selanjutnya, terdapat kesulitan dari pihak perpustakaan untuk mendapatkan pustakawan dan petugas perpustakaan sesuai bidang profesinya, menyebabkan proses pelayanan, pengelolaan, dan perawatan aset perpustakaan akan menjadi kurang efektif. Kemudian tim auditor menemukan pintu belakang pada ruang perpustakaan, yang mengakibatkan turunnya tingkat pengawasan keluar-masuk siswa di perpustakaan. Sedangkan yang terakhir prosedur penggunaan aset perpustakaan yang belum dibuat membuat kondisi ruangan perpustakaan akan terlihat kurang rapi karena meja, kursi, dan buku yang berserakan.

Terkait efisiensi, pergantian kurikulum dan revisi berkala dari Mendikbud dengan jangka waktu yang relatif cepat sehingga menyebabkan jumlah pembelian buku dan jumlah buku semakin banyak. Selain itu, perpustakaan SMA Kristen Satya Wacana hanya memiliki 2 orang petugas yang menyebabkan proses inventaris, pengawasan buku, dan pengelolaan buku memakan waktu yang cukup lama.

Pada poin keekonomisan, tim auditor menemukan bahwa tidak adanya pembimbingan dalam pengoperasian dan penerapan software pengelolaan perpustakaan yang menyebabkan pengelolaan dan pelayanan perpustakaan kurang maksimal. Kemudian, belum ada pengajuan kepada bagian sarana prasarana, belum ada kebutuhan loker untuk perpustakaan yang berisiko dapat mengakibatkan kehilangan barang pribadi milik pengunjung. Selanjutnya tim auditor menemukan belum adanya sistem terkomputerisasi yang memungkinkan untuk memastikan pengembalian buku yang dipinjam oleh siswa.

\section{Rekomendasi}

Hasil temuan audit menunjukkan bahwa terdapat beberapa kelemahan- 
kelemahan yang perlu diperhatikan oleh pihak sekolah. Rekomendasi yang dapat diberikan oleh tim auditor internal atas kelemahan-kelemahan tersebut yaitu :

Rekomendasi terkait temuan mengenai efektivitas yaitu: 1) memberikan sosialisasi atau memasang prosedur pengambilan buku yang benar untuk siswa, 2) menambah jumlah karyawan untuk fokus kepada tugas-tugas yang ada di perpustakaan (pelayanan, pengelolaan, dan perawatan, 3) menutup pintu belakang perpustakaan, atau memberikan tanda larangan masuk/keluar perpustakaan melalui pintu belakang perpustakaan 4) memasang tulisan mengenai prosedur penggunaan aset bagi pengunjung perpustakaan (contoh : kembalikan meja dan kursi seperti semula, jagalah kebersihan toilet, dll)

Rekomendasi terkait temuan mengenai efisiensi yaitu: 1) memberlakukan kebijakan terkait buku-buku tidak terpakai yang tersimpan dalam kardus, 2) menambah jumlah karyawan untuk fokus kepada tugas-tugas yang ada di perpustakaan (pelayanan, pengelolaan, dan perawatan), jika perlu mengadakan program magang untuk siswa SMK dan mahasiswa yang mengambil jurusan perpustakaan

Rekomendasi terkait temuan mengenai keekonomisan 1) memberikan pelatihan dan pembimbingan mengenai penerapan software pengelolaan buku perpustakaan, 2) membeli loker untuk penyimpanan tas pengunjung perpustakaan, 3) memberlakukan kebijakan untuk menjamin siswa mengembalikan buku secara keseluruhan (misal: tidak bisa registrasi ulang, atau tidak bisa mengambil ijazah jika belum mengembalikan buku)

\section{Komentar Auditee}

Komentar auditee terkait dengan rekomendasi yang pertama adalah bahwa auditee menerima rekomendasi dari tim auditor internal. Auditee juga setuju dengan masukan yang diberikan terkait temuan risiko, sebab, akibat dan rekomendasi serta berencana untuk menerapkan rekomendasi tersebut secara bertahap. Sebagai contoh, rekomendasi mengenai pintu darurat yang ada di perpustakaan agar ditutup atau memberikan tulisan larangan masuk/keluar. Namun rekomendasi terkait keterbatasan sumber daya manusia, hal tersebut memiliki kemungkinan lebih kecil untuk diterapkan. Auditee mengatakan bahwa kendala terkait sumber daya manusia karena sistem perekrutan karyawan dilakukan oleh yayasan pusat yang seringkali tidak sesuai dengan apa yang dibutuhkan oleh pihak sekolah. Rekomendasi terkait keterbatasan tempat untuk koleksi buku di perpustakaan juga kurang berjalan baik. Auditee mengatakan bahwa sebenarnya banyak gudang untuk menjadi tempat koleksi buku, namun adanya sistem sekolah yang tidak berjalan baik secara prosedural, sehingga membuat gudang tersebut dijadikan ruang kelas dan laboratorium siswa di sekolah.

\section{KESIMPULAN}

Audit operasional dilakukan dengan tujuan untuk meningkatkan efesiensi, efektivitas, dan keekonomisan kegiatan operasional perpustakaan SMA Kristen Satya Wacana. Untuk mencapai tujuan tersebut dilakukan audit dengan membandingkan kriteria dengan kondisi yang ada di perpustakaan. Berdasarkan kegiatan pengabdian masyarakat dalam bentuk audit yang telah dilakukan pada perpustakaan SMA Laboratorium Kristen Satya Wacana, telah dipaparkan beberapa hal yang berisiko mempengaruhi operasional perpustakaan. Temuan-temuan tersebut menandakan 
bahwa kegiatan operasional yang dilakukan belum sepenuhnya efektif, efisien dan ekonomis. Maka dari itu rekomendasi-rekomendasi yang diberikan diharapkan mampu membantu meningkatkan kegiatan operasional pihak perpustakaan SMA Laboratorium Kristen Satya Wacana, sehingga seluruh kegiatan operasional dapat berjalan secara efisen, efektif dan ekonomis sehingga dapat mewujudkan visi dan misi sekolah pada bidang perpustakaan.

\section{DAFTAR PUSTAKA}

Afrina, M., \& Ibrahim, A. (2012). Pengembangan Model Sistem Informasi Perpustakaan dengan Teknologi Informasi Berbasis Wireless Application Protocol (WAP) pada Universitas Sriwijaya. Jurnal Sistem Informasi (JSI), Vol 4 No 1, April , 425-436.

Anugrah, E. C., \& Tugiman, H. (2017). Pengaruh Audit Operasional dan Pengendalian Intern terhadap Manajemen Pergudangan (Studi Kasus pada Toserba Yogya Mitrabatik Tasikmalaya). eProceedings of Management 4 No. 2 .

Arifah, D. A. (2012). Penerapan Audit Kinerja (Audit Operasional) pada Sektor Swasta dan Pemerintah. Jurnal Keuangan dan Bisnis, Vol 4 No 3, November, 259-266.

Backlund, S., \& Thollander, P. (2015). Impact After Three Years of the Swedish Energy Audit Program. Energy (82), 54-60.

Fikri, M. A., Inapty, B. A., \& Martiningsih, R. S. (2016). Pengaruh Penerapan Standar Akuntansi Pemerintahan, Kompetensi Aparatur, dan Peran Audit Internal terhadap Kualitas Informasi Laporan Keuangan dengan Sistem Pengendalian Internal sebagai Variabel Moderating (Studi Empiris pada SKPD-SKPD di Pemprov NTB). Jurnal Akuntansi 9 .

Herawaty, N. (2013). Pengaruh Independensi, Keahlian Profesional, dan Pengalaman Auditor Internal terhadap Efektivitas Penerapan Struktur Pengendalian Intern (Hotel Kelas Melati di Kota Jambi). Jurnal Akuntansi, Vol 1 No 2, April , 129141.

Hijayati, R. A., Dzulkirom, M., \& Husaini, A. (2014). Analisis Audit Operasional dalam upaya meningkatkan Efisiensi, Efektivitas, dan Ekonomisasi Bagian Produksi (Studi pada PT. Semen Gresik (Persero)). Jurnal Administrasi Bisnis Vol. 12 No. 1 Juli .

Indonesia, P. R. (2004). Undang-undang Republik Indonesia Nomor 15 tahun 2004 Tentang Pemeriksaan Pengelolaan dan Tanggung Jawab Keuangan Negara. Jakarta, D.K.I Jakarta, Indonesia: Sekretariat Negara.

Kamal, M. (2012, Agustus 8). Dipetik Januari 29, 2019, dari Pusdiklatwas BPKP: https://www.google.com/url?sa=t\&rct=j\&q=\&esrc=s\&source=web\&cd=3\&ved $=2$ ahUKEwjM3c3ZlZLgAhWYbn0KHUt6B8oQFjACegQICBAC\&url=http\% 3A\%2F\%2Fpusdiklatwas.bpkp.go.id\%2Fasset $\% 2 \mathrm{Ffiles} \% 2 \mathrm{Fpost} \% 2 \mathrm{Fa} \_74 \% 2 \mathrm{~F}$ Teknik_penyusunan_PKA.pdf\&usg=AOvVaw1eb-tJTlqUz-H2JfT4DWCl

Karmudiandri, A. (2014). Peranan Audit Internal dalam Manajemen Risiko Bank. Media Bisnis Vol. 6 No.1 Edisi Maret, 19-26. 
Megasari, R. (2014). Peningkatan Pengelolaan Sarana dan Prasarana Pendidikan untuk Meningkatkan Kualitas Pembelajaran di SMPN 5 Bukittinggi. Jurnal Administrasi Pendidikan, Vol 2 No 1, Juni , 636-831.

Pramono, S. E. (2003). Transformasi Peran Internal Auditor dan Pengaruhnya Bagi Organisasi. Media Riset Akntansi, Auditing, dan Informasi, Vol 3 No 2, Agustus , 181-193.

Subamia, I. D., Artawan, P., \& Wahyuni, S. (2014). Analisis Kebutuhan Tata Kelola Laksana Laboratorium IPA SMP di Kabupaten Buleleng. Jurnal Pendidikan Indonesia, Vol 3 No 2, Oktober , 446-459.

Suharli, M. (2006). Audit Finansial, Audit Manajemen, dan Sistem Pengendalian Intern. Jurnal Bisnis dan Ekonomi, Vol 3 No 1 , 36-59.

Wahyuningsih, N., Halim, A., \& Wulandari, R. (2016). Peranan Audit Operasional dalam Menunjang Efektivitas Penjualan (Studi Empiris pada Perusahaan Daerah Air Minum Kabupaten Malang). Jurnal Riset Mahasiswa Akuntansi Vol. 4 No.1 
Desain dan Implementasi Audit Operasional pada Bagian Perpustakaan SMA Laboratorium Kristen Satya Wacana (Intan Chelsye R, Selvi Andriani, Intan Putri E, Ari Wicaksono, Rizky Sandhi Setyaki, Intiyas Utami, Suzy Novianti)

\section{LAMPIRAN}




\begin{tabular}{|c|c|c|c|c|c|c|}
\hline \multicolumn{7}{|c|}{ IDENTIFIKASI RISIKO } \\
\hline \multirow{2}{*}{$\begin{array}{l}\text { NO. } \\
\text { REGISTER }\end{array}$} & \multirow{2}{*}{$\begin{array}{l}\text { SUB-PROSES / } \\
\text { FASE KEGIATAN }\end{array}$} & \multirow{2}{*}{$\begin{array}{l}\text { SASARAN } \\
\text { SUB- } \\
\text { PROSES }\end{array}$} & \multicolumn{3}{|c|}{ RISIKO (INHEREN) YANG TERIDENTIFIKASI } & \multirow[t]{2}{*}{ KETERANGAN } \\
\hline & & & DESKRIPSI RISIKO & PENYEBAB & DAMPAK & \\
\hline 1 & 2 & 3 & 4 & 5 & 6 & 7 \\
\hline 1 & PENGADAAN & & 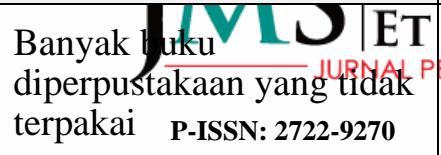 & 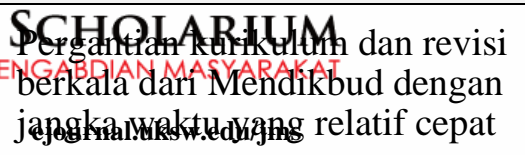 & $\begin{array}{l}\text { Jumlah pembelian buku dan } \\
\text { buku tersimpan akan semakin } \\
\text { banyak }\end{array}$ & \\
\hline 2 & PENGELOLAAN & & $\begin{array}{l}\text { Banyak buku rusak di } \\
\text { perpustakaan }\end{array}$ & $\begin{array}{l}\text { Buku rusak karena saat } \\
\text { mengambil buku, siswa kurang } \\
\text { berhati-hati, perbaikan hanya } \\
\text { menggunakan isolasi hitam } \\
\text { (lakban/cloth tape), usia buku } \\
\text { yang sudah cukup lama }\end{array}$ & $\begin{array}{l}\text { Jumlah buku yang rusak } \\
\text { kemungkinan akan bertambah }\end{array}$ & \\
\hline 3 & PENGELOLAAN & & $\begin{array}{l}\text { Buku hilang tanpa } \\
\text { sepengetahuan petugas } \\
\text { perpustakaan }\end{array}$ & $\begin{array}{l}\text { Terdapat pintu belakang pada } \\
\text { ruang perpustakaan }\end{array}$ & $\begin{array}{l}\text { Tingkat pengawasan keluar } \\
\text { masuk siswa di perpustakaan } \\
\text { semakin menurun }\end{array}$ & \\
\hline 4 & PENGELOLAAN & & $\begin{array}{l}\text { aset yang tidak berfungsi } \\
\text { sebagaimana mestinya }\end{array}$ & $\begin{array}{l}\text { Prosedur penggunaan aset } \\
\text { perpustakaan belum dibuat. }\end{array}$ & $\begin{array}{l}\text { Kondisi ruangan perpustakaan } \\
\text { akan terlihat kurang rapih } \\
\text { karena meja, kursi, dan buku }\end{array}$ & \\
\hline
\end{tabular}




\begin{tabular}{|c|c|c|c|c|}
\hline & & & & yang berserakan \\
\hline 5 & PENGELOLAAN & $\begin{array}{l}\text { pengelolaan perpustakaan } \\
\text { masih manual }\end{array}$ & $\begin{array}{l}\text { Tidak ada pembimbingan dalam } \\
\text { pengoperasian dan } \\
\text { pengaplikasian software } \\
\text { pengelolaan perpustakaan }\end{array}$ & $\begin{array}{l}\text { Pengelolaan dan pelayanan } \\
\text { perpustakaan kurang } \\
\text { maksimal }\end{array}$ \\
\hline 6 & PELAYANAN & $\begin{array}{l}\text { Pengelolaan dan } \\
\text { pelayanan perpustakaan } \\
\text { terbengkalai }\end{array}$ & $\begin{array}{l}\text { Sulit untuk mendapatkan } \\
\text { pustakawan dan petugas } \\
\text { perpustakaan sesuai bidang } \\
\text { profesinya }\end{array}$ & $\begin{array}{l}\text { Proses pelayanan, } \\
\text { pengelolaan, dan perawatan } \\
\text { aset perpustakaan akan } \\
\text { menjadi kurang efektif }\end{array}$ \\
\hline 7 & PELAYANAN & $\begin{array}{l}\text { pekerjaan petugas } \\
\text { perpustakaan memakan } \\
\text { waktu lama }\end{array}$ & $\begin{array}{l}\text { Petugas perpustakaan hanya } 2 \\
\text { orang }\end{array}$ & $\begin{array}{l}\text { Proses inventarisasi, } \\
\text { pengawasan buku, dan } \\
\text { pengelolaan buku akan } \\
\text { memakan waktu yang relatif } \\
\text { lama }\end{array}$ \\
\hline 8 & PELAYANAN & $\begin{array}{l}\text { barang milik pengunjung } \\
\text { tercampur dengan barang } \\
\text { milik pengunjung lain/ } \\
\text { ada barang milik } \\
\text { pengunjung yang hilang }\end{array}$ & $\begin{array}{l}\text { Belum ada pengajuan kepada } \\
\text { bagian sarana prasarana, belum } \\
\text { ada kebutuhan loker untuk } \\
\text { perpustakaan }\end{array}$ & $\begin{array}{l}\text { kemungkinan barang milik pengunjung } \\
\text { hilang karena tidak ada loker untuk } \\
\text { menyimpan tas pengunjung }\end{array}$ \\
\hline 9 & PELAYANAN & $\begin{array}{l}\text { banyak buku tidak } \\
\text { diketaui keberadaannya/ } \\
\text { buku hilang }\end{array}$ & $\begin{array}{l}\text { Belum ada sistem } \\
\text { terkomputerisasi yang } \\
\text { memungkinkan untuk memantau } \\
\text { pengembalian buku siswa }\end{array}$ & $\begin{array}{l}\text { Kemungkinan buku tidak } \\
\text { kembali akan semakin } \\
\text { bertambah }\end{array}$ \\
\hline
\end{tabular}



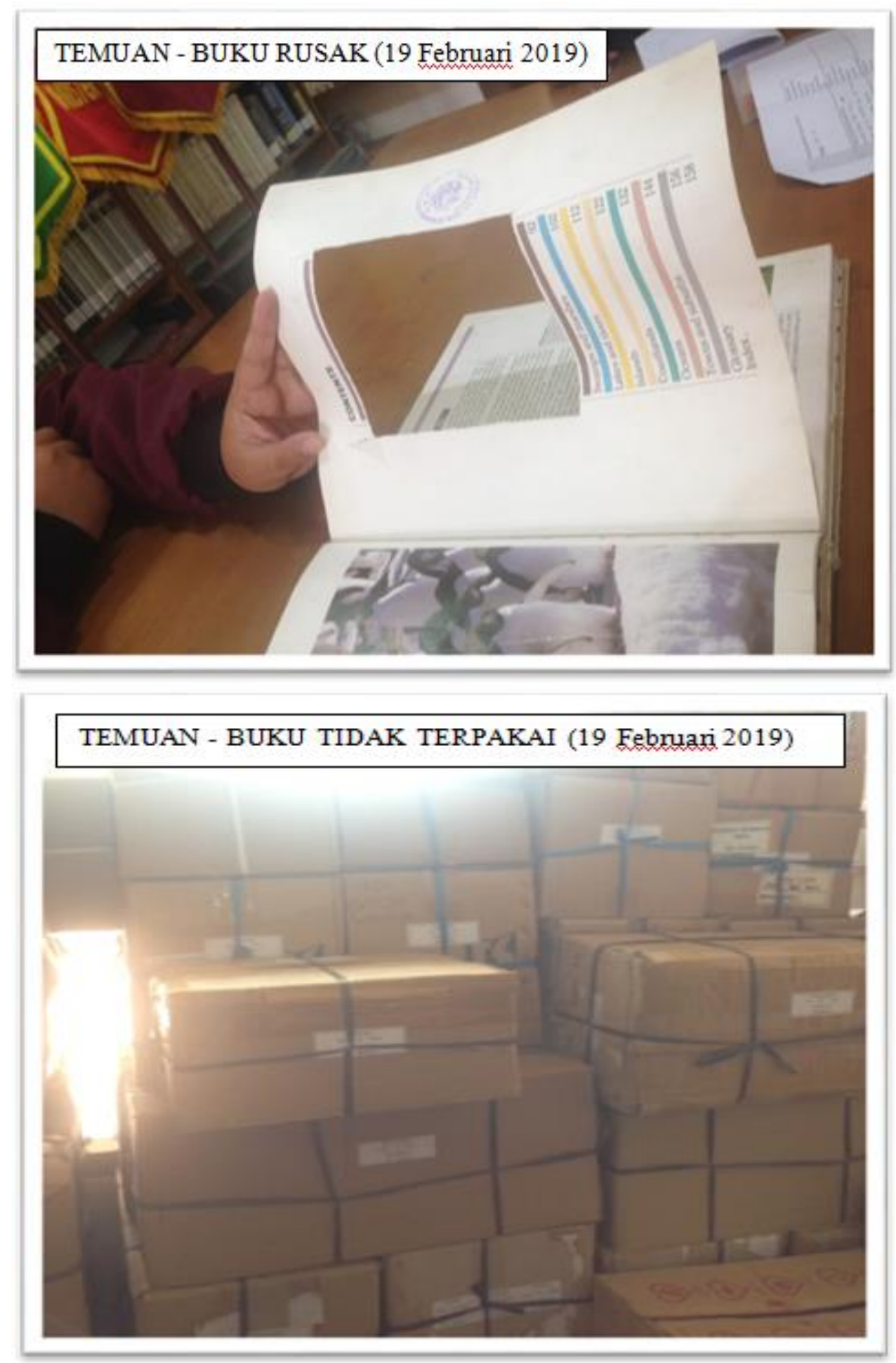

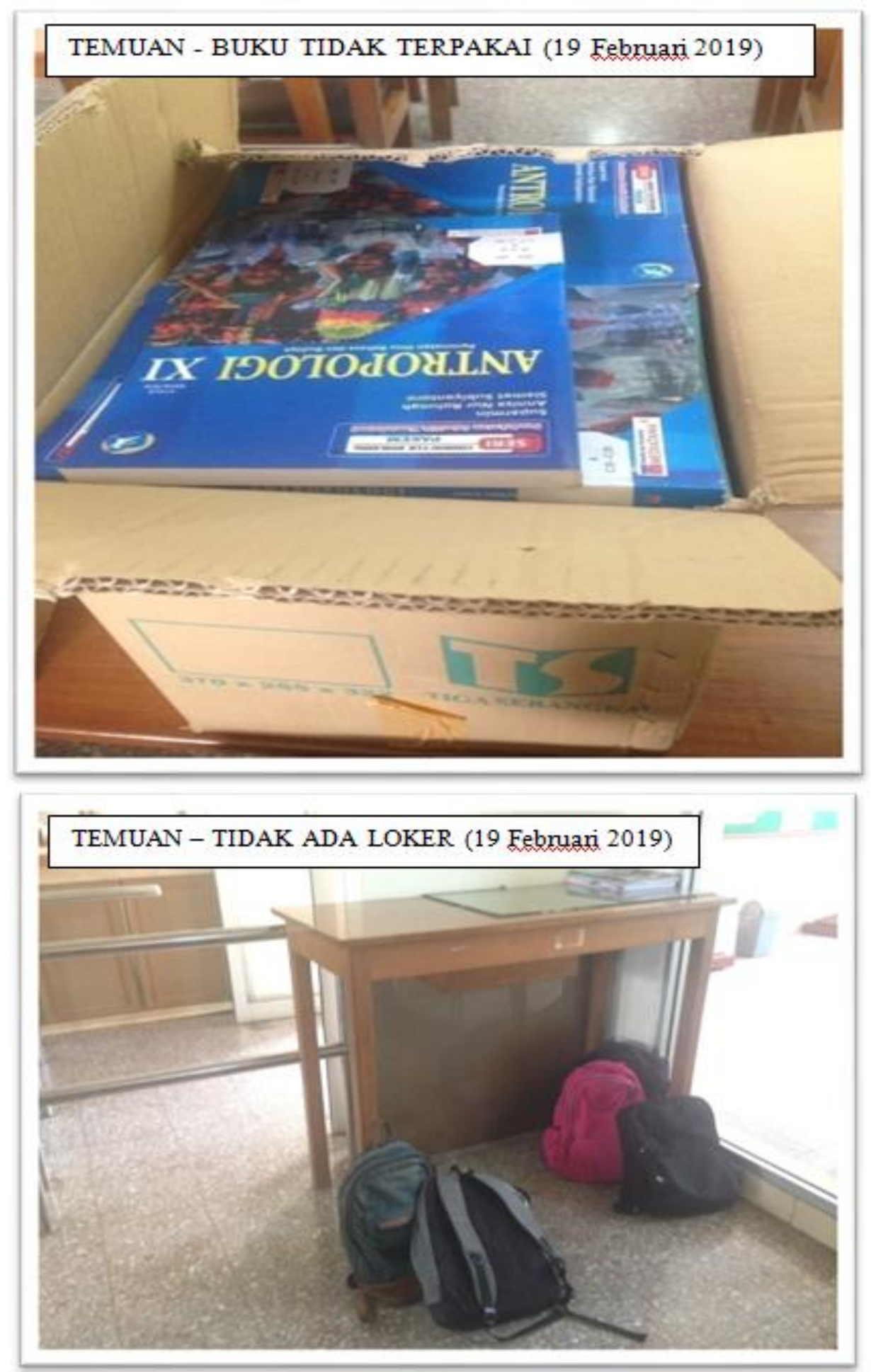


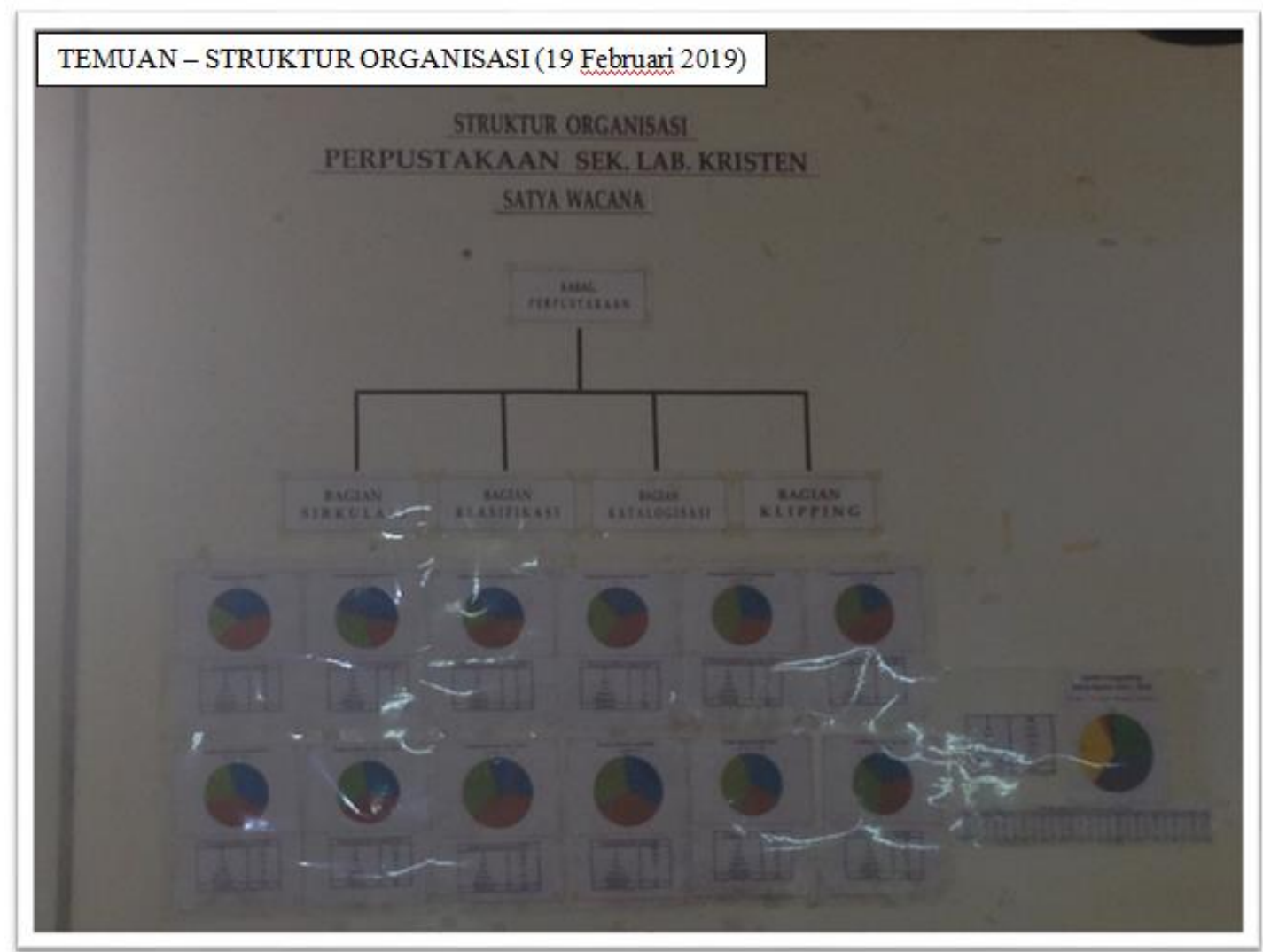

CATATAN : Struktur organisasi Perpustakaan SMA Kristen Satya Wacana tertulis 5 pegawai dengan bagian masing-masing, namun realisasinya hanya ada 2 pegawai yang mengerjakan semua aktivitas perpustakaan. 

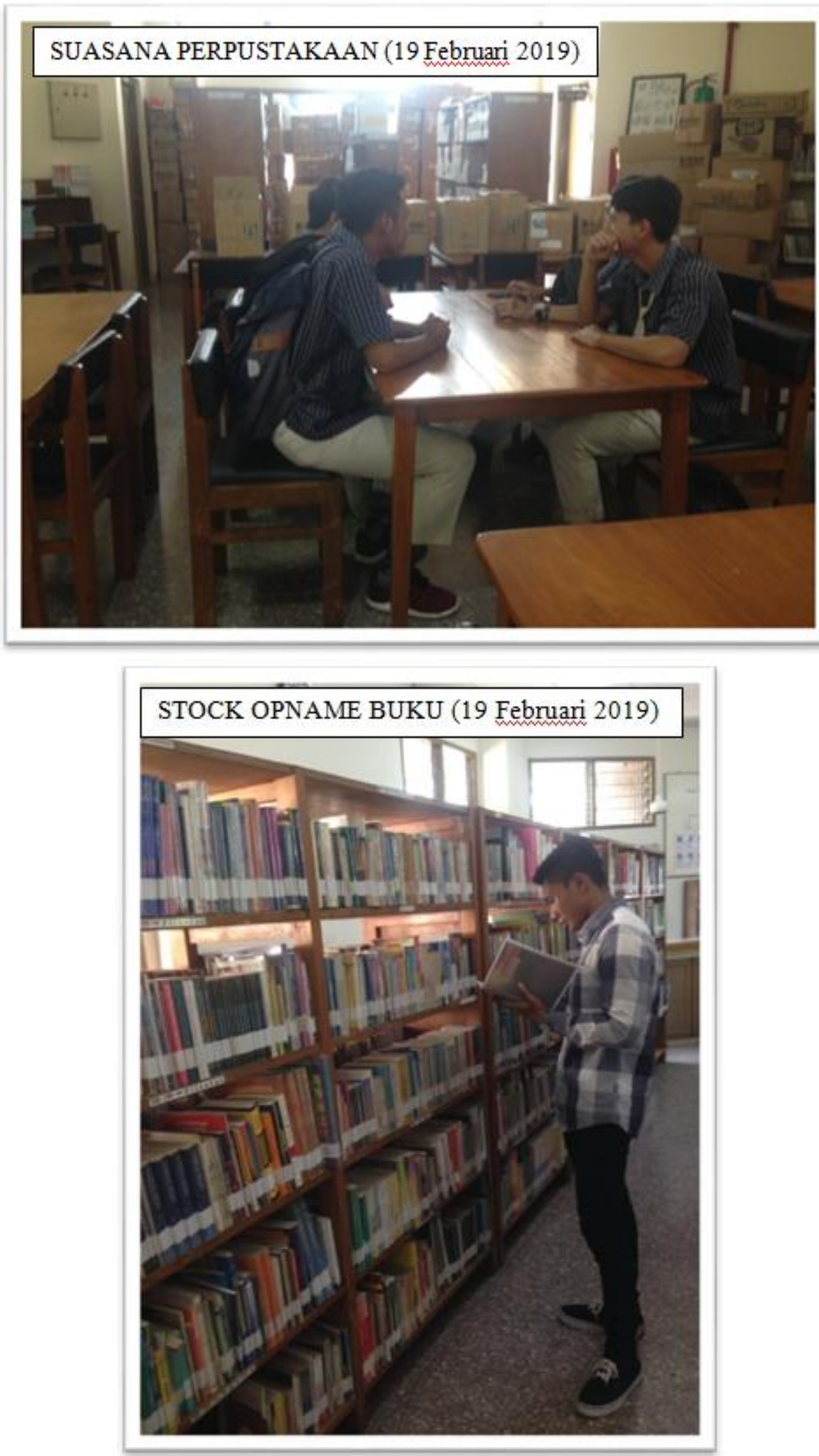


\begin{tabular}{|c|c|c|c|c|}
\hline \multicolumn{3}{|c|}{ Instansi : SMA Kristen Satya Wacana Salatiga } & Kode KKA & 001 \\
\hline \multicolumn{3}{|c|}{ Unit Auditee: Bagian Kurikulum } & Periode Audit & 2019 \\
\hline \multicolumn{5}{|c|}{ Program kerja audit: Implementasi Audit Operasional Perpustakaan } \\
\hline \multicolumn{5}{|c|}{ Tujuan Audit : Memastikan kegiatan operasional perpustakaan berjalan sesuai dengan 3E (efisien, efektif, ekonomis) } \\
\hline No & Risiko & Prosedur Audit & \multicolumn{2}{|c|}{ Waktu } \\
\hline 1. & Pembelian buku tidak sesuai & Membandingkan daftar pesanan dengan buku yang ada & 1 hari & 1 hari \\
\hline 2 & Pembelian buku berlebih & $\begin{array}{l}\text { Melakukan pengecekan daftar siswa dan membandingkan dengan daftar } \\
\text { pesanan }\end{array}$ & 1 hari & 1 hari \\
\hline 3 & Pembelian buku kurang & $\begin{array}{l}\text { Melakukan pengecekan daftar siswa dan membandingkan dengan daftar } \\
\text { pesanan }\end{array}$ & 1 hari & 1 hari \\
\hline 4 & Pengadaan aset tidak sesuai & Membandingkan daftar pesanan dengan buku yang ada & 1 hari & 1 hari \\
\hline 5 & Pengadaan aset tidak efektif & Melakukan pengecekan persediaan buku yang tidak terpakai & 1 hari & 1 hari \\
\hline 6 & Pengadaan aset berlebih & $\begin{array}{l}\text { Melakukan pengecekan daftar pesanan dan membandingkan dengan buku } \\
\text { yang ada }\end{array}$ & 1 hari & 1 hari \\
\hline 7 & Pengadaan aset kurang & $\begin{array}{l}\text { Melakukan pengecekan daftar pesanan dan membandingkan dengan buku } \\
\text { yang ada }\end{array}$ & 1 hari & 1 hari \\
\hline 8 & $\begin{array}{l}\text { Karyawan tidak sesuai dengan latar } \\
\text { belakang pendidikan }\end{array}$ & Melakukan observasi terhadap pekerjaan karyawan & 1 hari & 1 hari \\
\hline 9 & Karyawan tidak berkompeten & Melakukan observasi terhadap pekerjaan karyawan & 1 hari & 1 hari \\
\hline 10 & Kurangnya tenaga karyawan & Melakukan observasi terhadap pekerjaan karyawan & 1 hari & 1 hari \\
\hline 11 & Tenaga karyawan yang terlalu banyak & Melakukan observasi terhadap pekerjaan karyawan & 1 hari & 1 hari \\
\hline 12 & Karyawan tidak memiliki integritas & Melakukan observasi terhadap pekerjaan karyawan & 1 hari & 1 hari \\
\hline
\end{tabular}




\begin{tabular}{|c|c|c|c|c|}
\hline 13 & $\begin{array}{l}\text { Tidak adanya prosedur pembelian atau } \\
\text { pengadaan buku }\end{array}$ & $\begin{array}{l}\text { Melakukan konfirmasi dan melakukan pengecekan atas prosedur } \\
\text { pembelian atau pengadaan buku }\end{array}$ & 1 hari & 1 hari \\
\hline 14 & Tidak adanya prosedur pengadaan aset & $\begin{array}{l}\text { Melakukan konfirmasi dan melakukan pengecekan atas prosedur } \\
\text { pengadaan aset }\end{array}$ & 1 hari & 1 hari \\
\hline 15 & $\begin{array}{l}\text { Tidak adanya prosedur pengadaan } \\
\text { karyawan }\end{array}$ & $\begin{array}{l}\text { Melakukan konfirmasi dan melakukan pengecekan atas prosedur } \\
\text { pengadaan karyawan }\end{array}$ & 1 hari & 1 hari \\
\hline 16 & Tidak adanya prosedur pelepasan buku & $\begin{array}{l}\text { Melakukan konfirmasi dan melakukan pengecekan atas prosedur pelepasan } \\
\text { buku }\end{array}$ & 1 hari & 1 hari \\
\hline 17 & Tidak adanya prosedur pelepasan aset & $\begin{array}{l}\text { Melakukan konfirmasi dan melakukan pengecekan atas prosedur pelepasan } \\
\text { aset }\end{array}$ & 1 hari & 1 hari \\
\hline 18 & $\begin{array}{l}\text { Tidak adanya prosedur pelepasan } \\
\text { karyawan }\end{array}$ & $\begin{array}{l}\text { Melakukan konfirmasi dan melakukan pengecekan atas prosedur pelepasan } \\
\text { karyawan }\end{array}$ & 1 hari & 1 hari \\
\hline \multicolumn{2}{|c|}{ Pelaksana Audit } & Catatan penting & Disusun oleh & Disetujui oleh: \\
\hline \multicolumn{2}{|c|}{$\begin{array}{l}<\text { nama auditor internal }> \\
\text { tanggal:................... }\end{array}$} & & $\begin{array}{l}<\text { Ketua tim auditor internal }> \\
\text { tanggal:................... }\end{array}$ & $\begin{array}{l}<\text { Pimpinan auditor internal }> \\
\text { tanggal:.................... }\end{array}$ \\
\hline
\end{tabular}


(Lampiran tambahan terkait hasil kuisioner persepsi siswa atas layanan dan fasilitas perpustakaan)

\begin{tabular}{|c|c|c|c|c|c|c|c|}
\hline \multirow{3}{*}{ No } & \multirow{3}{*}{ Jenis Pernyataan } & \multicolumn{6}{|c|}{$\begin{array}{l}\text { Jumlah Total Pengisian Skor Tingkat Kepuasan } \\
\text { (siswa) }\end{array}$} \\
\hline & & \multicolumn{2}{|c|}{ Tidak Puas } & \multicolumn{2}{|c|}{ Netral } & \multicolumn{2}{|c|}{ Puas } \\
\hline & & 1 & 2 & 3 & 4 & 5 & 6 \\
\hline 1 & Pustakawan \& petugas perpustakaan memiliki penampilan yang rapi & 1 & 1 & 38 & 74 & 73 & 27 \\
\hline 2 & Pustakawan \& petugas perpustakaan ramah dan sopan dalam melayani pengunjung & 11 & 34 & 64 & 51 & 44 & 10 \\
\hline 3 & $\begin{array}{l}\text { Pustakawan \& petugas perpustakaan memberikan pelayanan dengan cepat dan } \\
\text { tepat }\end{array}$ & 3 & 2 & 59 & 70 & 62 & 18 \\
\hline 4 & $\begin{array}{l}\text { Pustakawan \& petugas perpustakaan tanggap dalam membantu pengunjung yang } \\
\text { sedang mengalami kesulitan }\end{array}$ & 5 & 13 & 57 & 61 & 59 & 19 \\
\hline 5 & Perpustakaan memiliki koleksi buku yang lengkap & 10 & 20 & 44 & 68 & 54 & 18 \\
\hline 6 & Perpustakaan memiliki akses yang mudah untuk menemukan lokasi buku & 3 & 9 & 56 & 62 & 61 & 23 \\
\hline 7 & Perpustakaan memiliki layanan akses katalog online & 40 & 48 & 66 & 40 & 14 & 6 \\
\hline 8 & Perpustakaan memiliki ruangan yang nyaman & 6 & 3 & 24 & 43 & 71 & 67 \\
\hline 9 & Suasana perpustakaan membuat saya untuk selalu berkunjung & 16 & 34 & 59 & 64 & 26 & 15 \\
\hline 10 & Perpustakaan bersih dan rapi & 2 & 2 & 17 & 43 & 75 & 75 \\
\hline 11 & Perpustakaan memiliki fasilitas yang lengkap & 9 & 12 & 60 & 66 & 47 & 20 \\
\hline 12 & Perpustakaan memiliki petunjuk dan tata cara penggunaan fasilitas & 13 & 16 & 54 & 59 & 50 & 22 \\
\hline 13 & Informasi mengenai ketersediaan koleksi buku : cepat, mudah dan akurat & 8 & 22 & 61 & 70 & 35 & 18 \\
\hline
\end{tabular}

